\title{
Bladder Spasm
}

National Cancer Institute

\section{Source}

National Cancer Institute. Bladder Spasm. NCI Thesaurus. Code C78210.

A sudden and involuntary contraction of the bladder wall. 